\title{
Evaluation of corneal endothelial cell loss in different grades of nucleus during phacoemulsification
}

\author{
Mehra $\mathbf{P}^{1}$, Verma RK ${ }^{2}$ \\ ${ }^{1}$ Dr Priyanka Mehra, Department of Ophthalmology, Affiliated with R.N.T. Medical College and Hospital, Udaipur, \\ Rajasthan, India. ${ }^{2}$ Dr Rajendra Kumar Verma, Department of Medicine, Affiliated with J. L. N, Medical College and \\ Hospital, Ajmer, Rajasthan, India
}

Address for Correspondence: PriyankaMehra, Email: drpriyankamhr@gmail.com

\begin{abstract}
Introduction: Phacoemulsification is now commonly used surgical procedure for cataract. The endothelial celldamage duringphacoemulsification can be caused by factors such as irrigation flow, turbulence and movementof fluids, presence of air bubbles, direct trauma caused by the instruments or lens fragments, and the phacoemulsification time and power needed to achieve nuclear emulsification. Grade of nucleus sclerosis affect the corneal endothelial cell loss in phacoemulsification. Methods: We concluded the study in 500 cases of cataract and found that loss of corneal endothelial cells increases with increasing the grade of nucleus sclerosis. Many methods have evolved in recent years to enhance the efficacy of nuclear management during phacoemulsification. The main purpose of these techniques is to mechanically break the nucleus into smaller fragments with the help of a second instrument, which helps decrease the use of ultrasound power in nuclear emulsification and reduces surgical time and limiting endothelial damage. Results: The average percentage loss of cells during our study was $14.5 \%$ which was highly significant (0.981). Conclusion: In our study we concluded that the endothelial cell damage increases with increase in nucleus hardness.
\end{abstract}

Keyword: Cataract, Corneal Endothelial Cell, Endothelial Cell Count, Nuclear Sclerosis, Phaco, Phacoemulsification.

\section{Introduction}

Corneal endothelial cells are non-replicative, and the loss of these cells is only compensated for by the migration, enlargement, and increasing heterogeneity of the cells [1]. The mean endothelial cell count (ECC) in the normal adult cornea ranges from 2000 to 2500 cells $/ \mathrm{mm} 2$, and the count continues to decrease with age. Previous cross-sectional studies have shown the normal attrition rate of corneal endothelial cells is 0.3$0.5 \%$ per year $[2,3]$. In developing countries such as India, where there is a cataract backlog, MSICS with intraocular lens (IOL) implantation promises to be a viable cost-effective alternative to phacoemulsification [4]. In India, approximately 5 million cataract surgeries are performed per year; therefore, it is important to determine the safest surgical technique for the endothelium. There is a paucity of data from India on the effect of small-incision cataract surgery (SICS) and phacoemulsification on the corneal endothelium

Manuscript received: $25^{\text {th }}$ Sept 2015

Reviewed: $30^{\text {th }}$ Sept 2015

Author Corrected: $18^{\text {th }}$ Oct 2015

Accepted for Publication: $25^{\text {th }}$ Oct 2015 (morphological and functional) was performed to assess the postoperative endothelial cell loss and change in endothelial morphology over a short period of time between the two commonly performed cataract techniques[5].

Phacoemulsification surgery is performed in a limited, confined space; however, securing adequate surgical space during an operation can decrease the risk of corneal endothelial cell loss as a result of the phacoemulsification procedure. Thus, anatomical and surgical factors, such as adequate anterior chamber depth (ACD), are important for preserving these cells from the mechanical and thermal damage that can occur during the procedure. Some studies have demonstrated that ACD did not affect endothelial cell loss after phacoemulsification surgery using a statistical correlation method $[6,7]$. However, these studies did not give careful consideration to other surgical factors, such as cumulative dissipated energy (CDE), ultrasound time (UST), and balanced salt solution (BSS) use as confounding factors. It is well known that UST and 
ultrasound power are important risk factors for endothelial cell loss after phacoemulsification [8]. Thus, we compared corneal endothelial cell loss according to different grades of nucleus hardness.

\section{Materials and Methods}

This is a prospective, interventional study conducted in patients having cataract that had presented to ophthalmology outdoor and operated at M. B. Govt. Hospital, Udaipur. Patients were followed up at 24 hours, one week, and 6 weeks after surgery for corneal endothelial cell loss by using specular microscope.

Inclusion Criteria: (1) Age group of patients - 40 -70 years. (2) Nucleus sclerosis graded from 1 to 4 . (3) Endothelial cell count b/w 1500- 3000 cells $/ \mathrm{mm}^{2}$.

Exclusion Criteria: (1) Patients with historyof diabetic mellitus. (2) History of previous intraocular surgery or ocular trauma.(3)Preoperative diagnosis of glaucoma. (4)Pseudo-exfoliation or corneal endothelial dystrophy. (5) Complicated cataract surgery (iris trauma, descemet's detachment). (6) Posterior capsule rupture with vitreous loss.

Surgical Technique- The eye and periocular area was painted and draped, eyelids were retracted with speculum. Two biplanar side portswere created with $15^{0}$ keratome. A cohesive ophthalmic viscosurgical device sodium hyaluronate $3 \%$ was injected in anterior chamber. Later on during subsequent phases of surgery dispersive OVD was used to deepen the anterior chamber and to expand the capsular bag. Continuous curvilinear capsulorrhexis was carried out with bent 26 gauge needle after staining anterior lens capsule by trypan blue dye when needed.A clear corneal tri-planar self-sealing incision was made with $2.2 \mathrm{~mm}$ blade. Hydro-dissection and hydro-delineation was performed to separate the lens from anterior capsule and nucleus from epinucleus respectively and free rotation of nucleus was ensured by using dialer.Nucleus fragmentation was done by phaco chop horizontal technique. Incision site enlarged with $2.8 \mathrm{~mm}$ keratome and remaining cortical matter was removed by irrigation and aspiration by help of manual or bimanual irrigation aspiration cannula. A foldable hydrophilic acrylic PC-IOL implanted in capsular bag. Residual viscoelastic wasremoved. The corneal wound sealed by hydration. Pad and patch was done. Patient was asked to consult next day in ophthalmic outdoor in morning.All other parameters like vacuum, power, irrigating fluid were kept constant.

ECD was measured on1st postoperative day, after 1 week, and after 6 weeks post-operatively.

The percentage of postoperative endothelial cell loss (ECLoss \%) was calculated as follows:

ECLoss $(\%)=([$ ECC-pre - ECC-post $] /$ ECC-pre $) \times 100$

\section{Results}

Table-1: Distribution of patients according to nucleus grade

\begin{tabular}{|l|l|l|}
\hline Nucleus grade & No. of patients & $\%$ \\
\hline NS1 & 95 & 19.00 \\
\hline NS2 & 170 & 34.00 \\
\hline NS3 & 130 & 26.00 \\
\hline NS4 & 105 & 21.00 \\
\hline Total & 500 & 100 \\
\hline
\end{tabular}

Maximum number of patients belongs to nucleus grade-2, which was 170 patients (34\%) followed by nucleus grade-3, 130 patients $(26 \%)$.

Table -2: Preoperative endothelial cell count according to nucleus grade

\begin{tabular}{|l|l|}
\hline Nucleus grade & Average Preoperative endothelial cell counts \\
\hline NS1 & 2588.11 \\
\hline NS2 & 2610.06 \\
\hline NS3 & 2524.96 \\
\hline NS4 & 2575.48 \\
\hline
\end{tabular}

Maximum endothelial cell density was with nucleus grade-2- 2610.06 cells $/ \mathrm{mm}^{2}$. 
Table-3:Postoperative endothelial count according to nucleus grade and per cent loss in endothelial cell count

\begin{tabular}{|c|c|c|c|c|c|c|c|}
\hline \multirow{3}{*}{$\begin{array}{l}\text { Nucleus } \\
\text { grade }\end{array}$} & \multirow{3}{*}{$\begin{array}{l}\text { Pre-operative } \\
\text { endothelial } \\
\text { cell count }\end{array}$} & \multicolumn{6}{|c|}{ Postoperative endothelial cell count } \\
\hline & & \multicolumn{2}{|l|}{1 day } & \multicolumn{2}{|l|}{1 week } & \multicolumn{2}{|l|}{6 week } \\
\hline & & Cell count & $\%$ loss & Cell count & $\%$ loss & Cell count & $\%$ loss \\
\hline NS1 & 2588.11 & 2277.74 & 11.99 & 2260.37 & 12.66 & 2243.84 & 13.30 \\
\hline NS2 & 2610.06 & 2283.35 & 12.52 & 2262 & 13.30 & 2245.47 & 13.97 \\
\hline NS3 & 2524.94 & 2167.00 & 14.18 & 2129.69 & 15.65 & 2100.08 & 16.83 \\
\hline NS4 & 2575.48 & 2162.62 & 16.03 & 2144.29 & 16.74 & 2127.29 & 17.40 \\
\hline
\end{tabular}

On post-operative day1 endothelial cell loss in nucleus grade 1 was average 311 cells $/ \mathrm{mm}^{2}(11.99 \%)$ and cell loss at 1 week and 6week was 327.74 cells $/ \mathrm{mm}^{2}(12.66 \%)$ and 344.27 cells $/ \mathrm{mm}^{2} \quad(13.30 \%)$ respectively.

In nucleus grade 2 cell loss at day1, 1 week and 6 week were 26.71 cells $/ \mathrm{mm}^{2}(12.52 \%), 347.13$ cells $/ \mathrm{mm}^{2}(13.30 \%)$ and 364.59 cells $/ \mathrm{mm}^{2}(13.97 \%)$ respectively.

In nucleus grade 3 cell loss at day1, 1 week and 6 week was 357.96 cells $/ \mathrm{mm}^{2}(14.18 \%), 395.27$ cells $/ \mathrm{mm}^{2}(15.65 \%)$ and 424.88 cells $/ \mathrm{mm}^{2}(16.83 \%)$ respectively.

In nucleus grade 4 cell loss was 412.86 cells $/ \mathrm{mm}^{2}(16.03 \%), 431.91 \mathrm{cells} / \mathrm{mm}^{2}(16.74 \%) \& 448.91 \mathrm{cells} / \mathrm{mm}^{2}(17.40 \%)$ at day1,1 week and 6 week respectively.

Table-4: Evaluation of post-operative Endothelial Cell Loss

\begin{tabular}{|l|l|l|l|l|}
\hline Nucleus grade & $\begin{array}{l}\text { Pre-operative } \\
\text { endothelial cell count }\end{array}$ & $\begin{array}{l}\text { Post-operative } \\
\text { endothelial cell count }\end{array}$ & Endothelial cell loss & \%age loss \\
\hline NS I & 2588.11 & 2260.65 & 327.46 & 12.6 \\
\hline NS II & 2610.06 & 2263.45 & 346.61 & 13.27 \\
\hline NS III & 2524.96 & 2132.25 & 392.71 & 15.5 \\
\hline NS IV & 2575.48 & 2144.73 & 430.75 & 16.7 \\
\hline MEAN & 2574.65 & 2200.39 & 373.04 & 14.5 \\
\hline
\end{tabular}

Mean post-operative endothelial cell loss in all grades of nucleus sclerosis at the end of 6 week was 373.04 cell $/ \mathrm{mm}^{2}$ with average percentage loss of cells $14.5 \%$ which was highly significant (0.981).

\section{Discussion}

Corneal transparency was regulated by an endothelial corneal pump function that can be disrupted by surgical trauma [9]. Endothelial cell loss was a major concern because a primary complication of cataract surgery is postoperative corneal decompensation. A high degree of surgical skill and accuracy in performing the operating technique were essential in reducing endothelial cell damage. Many factors such as nuclear density, mechanical contact with nuclear fragments, or instruments can increase cell loss [10, 11]. The risk of ECL was also increased by surgical complications such as capsular rupture and vitreous loss and advanced age [12].
This was a prospective clinical trial included 500 cases of age -related cataract whose mean age was 60 years. Males constituted $59.80 \%$ of the group and females $40.20 \%$. Preoperative and postoperative endothelial cell count was recorded and compared in different grades of nucleus whereas all the other parameters were kept constant. Post-operative findings revealed a highly statistically significant endothelial cell loss (correlation coefficient ' $r$ '=0.981). Mean Post-operative ECLoss \% was $14.5 \%$ with median range of 373.04 cells $/ \mathrm{mm} 2$. Endothelial cell loss \% increases with increasing grades of nucleus hardness from $12.6 \%$ in grade I to $16.7 \%$ in grade IV. ECLoss was greater in immediate postoperative period and in 1 st week. 
A study by Mohamed AE Soliman (2012) revealed a highly statistically significant endothelial cell loss (P < 0.001). The endothelial cell loss varied from 11 to 1149 cells/mm2 with a median (interquartile range) of 386cells/mm2 (184.5-686cells/mm2). Postoperative ECLoss \% ranged from $0.48 \%$ to $47.8 \%$ with a median (interquartile range) of $15.4 \% \quad(7.2 \%$ to $26.8 \%)$ according to the grade of nuclear opalescence [13].

Conflicting reports had found different ECLoss\% values that varied between $7 \%$ for conventional and $11.6 \%$ for bimanual phaco.Other reports cited a 3month postoperative endothelial cell loss between $4.6 \%$ and $15.6 \%$. A reduction of $20 \%-30 \%$ in endothelial cell loss after phaco was also reported by Storr-Paulsen et al [14]. The source of conflict in these studies might be attributed to variation in the patients' selection criteria and the technique and phaco technology used.26 Our study results that revealed a significant ECLoss\% which was correlated with the nuclear hardness in agreement with earlier reports by Vasavada et al and Lee et al [14, 15,16]. In a study by Lee et al, the percentage of endothelial cell loss was strongly correlated with the grade of nuclearopacity with a mean of $9.97 \%$ (for grade II) to $12.03 \%$ (for grade IV). The difference in the ECLoss \% in our study could be attributed to the fact that our study included a higher grade of nuclear hardness $(21 \%$ of our cases were grade IV) which was not the case in the study by Lee et al (they included only cases of grade IV or less), while Vasavada et al had used a different system for grading nuclear hardness.

\section{Funding: Nil,Conflict of interest: None. Permission of IRB: Yes}

\section{Conclusion}

This prospective study of determining endothelial cell loss after phacoemulsification comprises 500 patients which were selected by random sampling and were followed for a period of 6 weeks. Incidence of endothelial cell loss seems to increase with increase in nucleus hardness from $12.6 \%$ in grade $\mathrm{I}$ to $16.7 \%$ in grade IV with average cell loss of $14.5 \%$. ECLoss was greater in immediate postoperative period and in 1 st week.

Micro-coaxial phacoemulsification was efficient in removing non-complicated cataract; however a statistically significant endothelial cell loss was noted, especially with increase nucleus hardness.However good visual outcome shows that this procedure can be practiced as a routine surgery.

Acknowledgement -We want to give special thanks to department of ophthalmology, M.B.GOVT. Hospital, R. N. T. Medical College, Udaipur, Rajasthan.

\begin{abstract}
Abbreviations
ECC-Endothelial cell count. ECC-pre -Endothelial cell count pre-operative. ECC-port - Endothelial cell count post-operative. IOL-Intraocular lens. SICS-Smallincision cataract surgery ACD-Anterior chamber depth MSICS- Manual small incision cataract surgery. OVDOphthalmic viscosurgicaldevices. EC Loss\%Endothelial cell loss percentage
\end{abstract}

\section{References}

1. Waring GO 3rd, Bourne WM, Edelhauser HF, Kenyon KR. The corneal endothelium. Normal and pathologic structure and function. Ophthalmology. 1982 Jun;89(6):531-90.

2. Yee RW, Matsuda M, Schultz RO, Edelhauser HF. Changes in the normal corneal endothelial cellular pattern as a function of age. Curr Eye Res. 1985 Jun;4(6):671-8.

3. Carlson KH, Bourne WM, McLaren JW, Brubaker RF. Variations in human corneal endothelial cell morphology and permeability to fluorescein with ag e. Exp Eye Res. 1988 Jul;47(1):27-41.

4. Muralikrishnan R, Venkatesh R, Prajna NV, Frick $\mathrm{KD}$. Economic cost of cataract surgery procedures in an established eye care centre in Southern India. Ophthalmic Epidemiol. 2004 Dec;11(5):369-80.

5. Sunil Ganekal and Ashwini Nagarajappa. Comparison of Morphological and Functional Endothelial Cell Changes after Cataract Surgery: Phacoemulsification versus Manual Small-Incision Cataract Surgery. Middle East Afr J Ophthalmol. 2014 Jan-Mar; 21(1): 56-60.doi: 10.4103/0974-9233.124098.

6. T. Walkow, N. Anders, and S. Klebe, "Endothelial cell loss after phacoemulsification: relation to preoperative and intraoperative parameters. Journal of Cataract \& Refractive Surgery. 2000;26(5): 727-732. 
7. Reuschel A, Bogatsch H, Oertel N, Wiedemann R. Influence of anterior chamber depth, anterior chamber volume, axial length, and lens density on postoperative endothelial cell loss. Graefes Arch Clin Exp Ophthalmol. 2015 May;253(5):745-52. doi: 10.1007/s00417-015-2934-1. Epub 2015 Mar 1.

8. O'Brien PD, Fitzpatrick P, Kilmartin DJ, Beatty S. Risk factors for endothelial cell loss after phacoemulsification surgery by a junior resident. J Cataract Refract Surg. 2004 Apr;30(4):839-43.

9. Maurice DM. The cornea and sclera. In: Davson H (Ed.). The Eye, 3rd edn. Academic Press: Orlando; 1984 , p. 85.

10. Hayashi K, Hayashi H, Nakao F, Hayashi F. Risk factors for corneal endothelial injury during phacoemulsification. J Cataract Refract Surg. 1996 Oct;22(8):1079-84.

11. Davison JA. Endothelial cell loss during the transition from nucleus expression to posterior chamber-iris plane phacoemulsification. J Am Intraocul Implant Soc. 1984 Winter;10(1):40-3.

12. Bourne RR, Minassian DC, Dart JK, Rosen P, Kaushal S, Wingate N. Effect of cataract surgery on the corneal

endothelium: modern phacoemulsification compared wi th extracapsularcataract surgery. Ophthalmology. 2004 Apr;111(4):679-85.

13. Mohamed AE Soliman, Mahdy, Mohamed Z Eid ,Mahmoud Abdel-Badei , Mohammed, Amr Hafez, Jagdish Bhatia. Relationship between Endothelial Cell Loss andMicrocoaxial Phacoemulsification Parameters inNoncomplicated Cataract Surgery. Clinical Ophthalmology 2012; (6): 503-510.

14. Storr-Paulsen A, Norregaard JC, Ahmed S, StorrPaulsen T, Pedersen TH. Endothelial cell damage after cataract surgery: divide-and-conquer versus phaco-chop technique. J Cataract Refract Surg. 2008 Jun;34(6):9961000. doi: 10.1016/j.jcrs.2008.02.013.

15. Lee KM, Kwon HG, Joo CK. Microcoaxial cataract surgery outcomes: comparison of $1.8 \mathrm{~mm}$ system and $2.2 \mathrm{~mm}$ system. J Cataract Refract Surg. 2009 May;35(5):874-80. doi: 10.1016/j.jcrs.2008.12.031.

16. Vasavada V, Raj SM, Vasavada AR. Intraoperative performance and postoperative outcomes of microcoaxial phacoemulsification. Observational study. J Cataract Refract Surg. 2007;33(6):1019-1024.

\section{How to cite this article?}

Mehra P, Verma RK. Evaluation of corneal endothelial cell loss in different grades of nucleus during phacoemulsification. Int J Med Res Rev 2015;3(10):1128-1132. doi: 10.17511/ijmrr.2015.i10.204. 